\title{
Polychaete zonation on sandy beaches of São Sebastião Island, São Paulo State, Brazil
}

\author{
Margarete de O. Reis; Eloísa H. Morgado; Márcia R. Denadai \& A. Cecília Z. Amaral \\ Instituto de Biologia, UNICAMP \\ Departamento de Zoologia \\ (Caixa Postal 6109, 13083-970 Campinas, SP, Brasil)
}

- Abstract: This study was performed in the intertidal zone of Barra Velha, Perequê, and Engenho d'Água beaches, located on São Sebastião Island (São Paulo State, Brazil), to assess the composition, abundance, and zonation of the polychaete community in the intertidal zone. Four structurally different sectors were established, two on Barra Velha (I and II), one on Perequê, and one on Engenho d'Água. Each sector was divided into 3 tidal levels (lower, middle, and upper), in which 5 or 6 random samples were taken seasonally using a corer of $0.01 \mathrm{~m}^{2}$ in area. Laeonereis acuta, Capitella capitata, and Heteromastus filiformis dominated in the upper tidal levels, and Scoloplos (Leodamas) sp. and Cirriformia tentaculata in the lower levels. The structural complexity of Engenho d'Água, caused by rocky fragments mixed with sand, supported the richest and most diverse polychaete fauna of all the sectors. The salinity of the interstitial water and the organic matter content were the principal factors related to the zonation patterns at these sites.

- Resumo: Este trabalho foi realizado na região entremarés das praias Barra Velha, Perequê e Engenho d'Água, situadas na Ilha de São Sebastião (Estado de São Paulo, Brasil), com o objetivo de estudar a composição, abundância e zonação da taxocenose dos poliquetas. Quatro setores estruturalmente diferentes foram delimitados, sendo dois na Barra Velha (I e II), um no Perequê e um no Engenho d'Água. Cada setor foi dividido em 3 níveis entremarés (inferior, intermediário e superior), nos quais 5-6 amostras aleatórias foram tomadas sazonalmente utilizando um delimitador com $0,0 \mathrm{~lm}^{2}$ de área. Laeonereis acuta, Capitella capitata e Heteromastus filiformis ocorreram predominantemente nos niveis superiores e Scoloplos (Leodamas) sp. e Cirriformia tentaculata nos inferiores. A complexidade estrutural do Engenho d'Água, caracterizado por fragmentos rochosos misturados ao sedimento, sustentou a fauna de poliquetas mais rica e diversificada dentre os setores. A salinidade da água intersticial e o teor de matéria orgânica foram os principais parâmetros determinantes da zonação nestes locais.

- Descriptors: Polychaetes, Sandy beaches, Intertidal, Zonation, Macrofauna.

- Descritores: Poliquetas, Praias arenosas, Entremarés, Zonação, Macrofauna.

\section{Introduction}

The intertidal zone of sandy beaches is a rigorous environment, where the organisms are adapted to live in a gradient from marine to terrestrial conditions. This gradient, generated by tidal cycles, causes specific adaptations that result in different zones of distribution (Bally, 1983).

Some of the physical and biological factors that influence the faunal composition and distribution in sandy beaches are: desiccation, wave action, currents, sediment type, beach slope, temperature, sediment moistness, interstitial water salinity, organic matter content, seasonal variation of the fauna, competition, and predation (Vohra, 1971; Brown \& McLachlan, 1990; McLachlan \& Jaramillo, 1995). According to Dexter (1988), the factors related to wave action are most relevant. The opportunist species tend to occur in particular levels of the beach, although their spatial and temporal distribution can vary in response to environmental instability (Veloso et al., 1997). 
Two universal patterns of zonation on sandy beaches are known. Dahl (1953) studied the crustacean fauna and established 3 zones: supralittoral, midlittoral, and sublittoral. The alternative model proposed by Salvat (1964) establishes 4 zones, defined on the basis of water content from high to low beach levels: dry sand zone; retention zone, where the sediment retains a small amount of water and is well oxygenated; resurgence zone, where water circulates among the sand grains, however without reaching saturation; and saturation zone, where the sediment is constantly saturated by water, with low circulation and oxygenation. Salvat's dry sand zone corresponds to Dahl's supralittoral, the retention and resurgence zones to the midlittoral, and the saturation zone to the sublittoral fringe (McLachlan et al., 1981; Wendt \& McLachlan, 1985).

McLachlan (1983) stated that a zonation pattern with distinct edges has never been described for sandy beaches. Perhaps the only rigorous model is that proposed by Brown \& McLachlan (1990), who recognized two zones: that composed of airbreathers, and that where all organisms are waterbreathers. There are several differences among the zonation patterns proposed for sandy beaches, probably because of their complexity, heterogeneity, and instability (Wendt \& McLachlan, 1985; Veloso et al., 1997).

Most zonation studies in exposed or partly sheltered sandy beaches have treated the crustaceans and molluscs, the most abundant groups in these environments. The beaches selected for the present study are located in sheltered areas in the São Sebastião Channel, and support a rich polychaete infauna (Amaral et al., 1995), a group commonly reported in sheltered sand flats, where they are distributed homogeneously (Gruet, 1974). Our study provides information about the polychaete composition, abundance, and zonation in four intertidal sandy beach environments on São Sebastião Island, considering the importance of environmental factors for the community structure.

\section{Area of study}

Perequê, Barra Velha, and Engenho d'Água beaches are located on São Sebastião Island, in the central region of the São Sebastião Channel $\left(23^{\circ} 47^{\prime} \mathrm{S} ; 45^{\circ} 27^{\prime} \mathrm{W}\right)$ on the northern coast of São Paulo State, Brazil (Fig. 1). These are low energy sandy beaches subjected to semidiurnal tides with $2 \mathrm{~m}$ maximum tidal range (Furtado \& Mahiques, 1990). The morphodynamism of these areas was not investigated due to the absence of waves, which occur only during sea storms.
Four sectors were delimited, based on environmental characteristics: Barra Velha I, located in the southern end of the beach, has coarse sand grains and a small rivulet, with typical mangrove vegetation; Barra Velha II, in the central region of the beach, is a mudflat, composed of fine sediments; and Perequê and Engenho d'Água are characterized by sand bars covered by the seagrass Halodule sp. in the former, and coarse sand and rock fragments (about 50 to $300 \mathrm{~mm}$ in diameter) in the latter. The intertidal zones of all the sectors, as the adjacent areas, have gentle slopes.

\section{Materials and methods}

The study sectors were divided into 3 tidal levels: lower, the nearest to the water line; upper, adjacent to the dry zone; and middle, between the lower and upper. The width of each tidal level was determined according to the intertidal distance considering visual aspects, as the degree of water saturation in the sediment and distribution of known species. A cylindrical corer with $0.01 \mathrm{~m}^{2}$ area and $20 \mathrm{~cm}$ in depth was used for quantitative collections. The samples were taken at low spring tide, at four seasons in each sector: winter (AugustSeptember/92), spring (October-November/92), summer (March/93), and autumn (May/93). Initially (winter), 5 random samples were taken in each level, and after analysis of the results, 6 samples/level/period were taken, 3 of these fixed (selected among the 5 from the winter sample) and 3 randomly sorted. The total sampled area in each sector was $0.69 \mathrm{~m}^{2}$ (69 samples). In the laboratory, the sediment (biological material) was washed with seawater over two superimposed sieves of 1.0 and $0.5 \mathrm{~mm}$ mesh. The polychaetes retained were preserved in $70 \%$ alcohol and identified to species.

Air and sediment temperature, interstitial water salinity, sediment grain size $\left[\phi=-\log _{2}\right.$ (mean grain size in $\mathrm{mm}$ )] (Suguio, 1973), and calcium carbonate and organic matter content in the sediment (Amoureux, 1966) were obtained for each level.

Two-way analysis of variance (ANOVA) was performed to compare environmental variables among sectors and tidal levels. Diversity (H') (Shannon-Wiener index in $\log _{2}$ ) and evenness $\left(\mathrm{J}^{\prime}\right)$ (Krebs, 1989) were calculated for each sector and level. Canonical Correspondence Analysis [Hill's (1979) method, data standardized by "power transform", given equal weight to each variable], was used to establish relationships between polychaete distribution and environmental variables. 


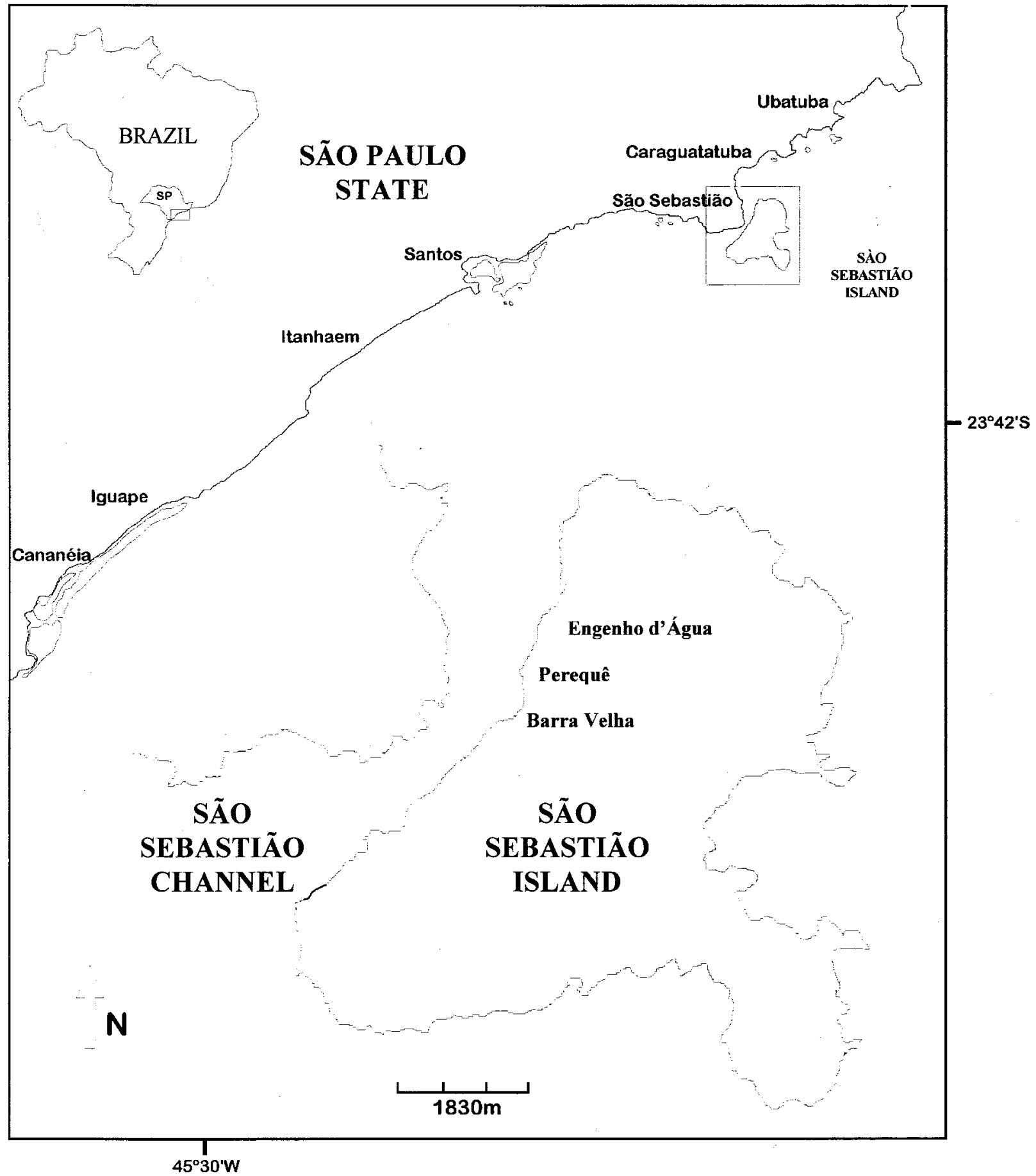

Fig. 1. Location of the sand beaches studied in the São Sebastião Island (São Sebastião Channel, São Paulo State, Brazil).

\section{Results}

Air and sediment temperatures ranged from $20^{\circ} \mathrm{C}$ (winter) to $33^{\circ} \mathrm{C}$ (summer). The mean values $(+1$ SE) of salinity, grain size, sorting coefficient, and calcium carbonate and organic matter contents are shown in Figure 2, and the results of two-way ANOVA for comparisons of the environmental variables among sectors and tidal levels are presented in Table 1. Salinity ranged from 6 to $35 \%$, the lowest values being recorded in Barra Velha I, followed by Barra Velha II, Perequê, and Engenho d'Água 

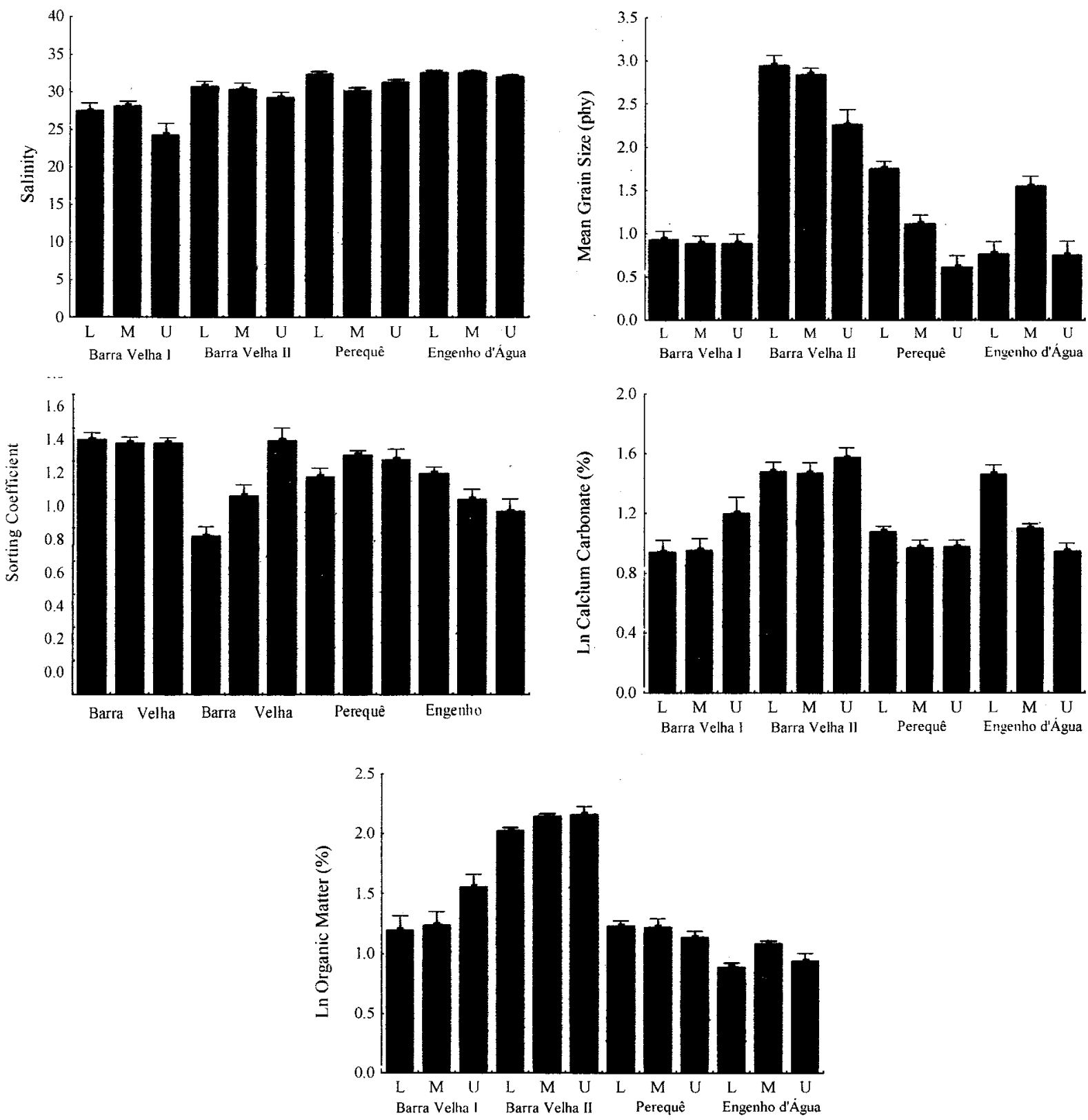

Fig. 2. Mean values ( +1 Standard error) of salinity (\%o), sediment grain size (phy), sorting coefficient (phy). calcium carbonate content $(\%)$, and organic matter content $(\%)$ at the tidal levels and sampled sectors.

At Barra Velha I, the sediment ranged from coarse sand to silt, with coarser grains dominating, while fine grains were more abundant in Barra Velha. II. Greater variations in grain size were observed at Perequê, where the coarser grains occurred in the upper tidal level and the finer ones in the lower. At Engenho d'Água the sediment was heterogeneous, with coarse sand dominating in the lower and upper tidal levels, and medium grains in the middle. In general, all the sectors had poorly sorted sediments.

Calcium carbonate varied less than organic matter content. At Engenho d'Água the values of calcium carbonate in the lower tidal level were significantly higher than in the other levels. The highest organic matter content was observed in Barra Velha II, where the mean values reached $8 \%$, decreasing from the upper to lower tidal levels. 
Table 1. Two-way ANOVA for the effects of study sectors (Barra Velha I, Barra Velha II, Perequê and Engenho d'Água) and tidal levels on salinity, sediment grain size, sorting coefficient, calcium carbonate content, and organic matter content. (df, degrees of freedom; MS, mean square).

\begin{tabular}{lcccc}
\hline \multicolumn{1}{c}{ Source of variation } & df & MS & F & p \\
\hline Salinity (\%o) & 3 & 364.004 & 31.671 & $<0.001$ \\
Sector & 2 & 51.755 & 4.503 & 0.012 \\
Tidal level & 6 & 19.966 & 1.737 & 0.113 \\
$\quad$ Sector *Tidal level & & & & \\
Sediment grain size (phy) & 3 & 48.164 & 131.041 & $<0.001$ \\
$\quad$ Sector & 2 & 6.726 & 18.299 & $<0.001$ \\
Tidal level & 6 & 2.907 & 7.910 & $<0.001$ \\
Sector *Tidal level & & & & \\
Sorting coefficient (phy) & 3 & 1.501 & 20.713 & $<0.001$ \\
Sector & 2 & 0.289 & 3.993 & 0.020 \\
Tidal level & 6 & 0.668 & 9.226 & $<0.001$ \\
Sector *Tidal level & & & & \\
Calcium carbonate content (\%) & 3 & 3.653 & 35.420 & $<0.001$ \\
Sector & 2 & 0.323 & 3.135 & 0.045 \\
Tidal level & 6 & 0.656 & 6.363 & $<0.001$ \\
Sector *Tidal level & & & & \\
Organic matter content $(\%)$ & 3 & 16.966 & 138.611 & $<0.001$ \\
Sector & 2 & 0.308 & 2.517 & 0.083 \\
Tidal level & 6 & 0.328 & 2.680 & 0.015 \\
Sector *Tidal level & & &
\end{tabular}

A total of 36 species and 1822 individuals of polychaetes were taken in the study areas. Table 2 shows the species composition, occurrence, and density in each sector. Laeonereis acuta, Capitella capitata, and Heteromastus filiformis were abundant in Barra Velha I and II, representing approximately 88 and $51 \%$, respectively, of the total number of individuals. Scoloplos (Leodamas) $\mathrm{sp}$. was the dominant species in Barra Velha II (35.2\%) and in Perequê (42.9\%). Cirriformia tentaculata showed greater abundance $(45.2 \%)$ in Engenho d'Água. The highest species richness was found in Engenho d'Água, followed by Perequê, Barra Velha II, and Barra Velha I.

The spatial distribution of the more abundant species in each sector is shown in Figs. 3-6. The species L. acuta, C. capitata, and H. filiformis occurred over the entire intertidal region of Barra Velha I, where the first two species reached higher densities in the upper tidal levels. Heteromastus filiformis was abundant in the lower level. Species with low densities, such as Marphysa sp. and Isolda pulchella, were frequent over the entire intertidal area. Both diversity and richness tended to increase from the upper to lower tidal levels of this sector (Tab. 3).

The middle tidal level of Barra Velha II was the richest (16 species) in comparison with the lower and upper (12 species in both). Capitella capitata, H. filiformis, and L. acuta had similar distribution patterns, decreasing in abundance from upper to lower tidal levels. Contrariwise, Scoloplos (Leodamas) sp. had its highest density in the lower tidal level. A higher richness and lower number of individuals characterized Perequê Site. Marphysa sp., Scoloplos (Leodamas) sp., Aricidea fragilis, C. tentaculata, and Armandia agilis were frequent over the entire intertidal region, despite their low density. Scoloplos (Leodamas) sp. was the most abundant species in this sector, occurring mainly in the middle tidal level. Diopatra cuprea and $A$. fragilis were relatively abundant in the upper and middle levels respectively. Engenho d'Água showed the highest richness, but was characterized by the dominance of Cirriformia tentaculata, leading to a reduction in diversity in the lower tidal level. Owenia fusiformis and Scolelepis squamata reached their highest abundance in the upper tidal levels of this sector.

The diversity of the Barra Velha I and II sectors was highest in the lower and middle tidal levels, respectively, while in the Perequê and Engenho d'Água sectors diversity was highest in the upper level (Tab. 3). Evenness followed the diversity, increasing from the lower to upper tidal level in the sectors on Barra Velha II and Engenho d'Água, inversely at Barra Velha I, and was uniform in the Perequê sector. 
Table 2. Occurrence and density of species at the sectors studied $\left(0.69 \mathrm{~m}^{2} / \mathrm{sector}\right)$.

\begin{tabular}{|c|c|c|c|c|}
\hline Species & $\begin{array}{c}\text { Barra } \\
\text { Velha I }\end{array}$ & $\begin{array}{c}\text { Barra } \\
\text { Velha II }\end{array}$ & Perequê & $\begin{array}{l}\text { Engenho } \\
\text { d'Água }\end{array}$ \\
\hline Sthenelais boa (Johnston, 1839) & & & & 4 \\
\hline Eurythoe complanata (Pallas, 1766) & & & & 4 \\
\hline Sigambra grubei Müller, 1858 & 1 & 2 & & \\
\hline Parandalia americana (Hartman, 1947) & & 14 & 3 & \\
\hline Langerhansia cornuta (Rathke, 1843) & & & & 27 \\
\hline Laeonereis acuta Treadwell, 1923 & 223 & 93 & & \\
\hline Neanthes sp. & & & & 6 \\
\hline Glycinde multidens Müller. 1858 & & 3 & 2 & 6 \\
\hline Goniada littorea Hartman, 1950 & & 1 & 3 & 3 \\
\hline Goniada brunnea Treadwell, 1906 & & & 1 & \\
\hline Diopatra cuprea $(\mathrm{Box}, 1802)$ & 1 & 4 & 29 & 4 \\
\hline Lysidice ninetta A. \& M. Edwards. 1833 & & & & 2 \\
\hline Marphysa sp. & 11 & 25 & 6 & 37 \\
\hline Nematonereis hebes Verril, 1900 & 1 & & 3 & \\
\hline Lumbrineris tetraura (Schmarda, 1861) & & 5 & 1 & 1 \\
\hline Naineris setosa $($ Verril, 1900) & & & 2 & 16 \\
\hline Scoloplos (Leodamas) sp. & 4 & 251 & 85 & 2 \\
\hline Aricidea fragilis Webster, 1879 & & 1 & 24 & 2 \\
\hline Polydora websteri Hartman, 1943 & 1 & & & \\
\hline Prionospio steenstrupi Malmgren. 1867 & & & & 12 \\
\hline Scolelepis squamata (Müller, 1806) & & 12 & 1 & 23 \\
\hline Magelona sp. & & 1 & & \\
\hline Magelona variolamellata Bolivar \& Lana, 1986 & & 2 & 1 & 4 \\
\hline Cirriformia tentaculata (Montagu, 1808) & 16 & & 5 & 214 \\
\hline Armandia agilis Andrews. 1891 & & 1 & 7 & 1 \\
\hline Sternaspis capillata Nonato, 1966 & & 10 & 1 & \\
\hline Capitella capitata (Fabricius, 1780) & 135 & 147 & & 2 \\
\hline Heteromastus filiformis (Claparède, 1869) & 42 & 123 & 6 & 3 \\
\hline Mediomastus californiensis Hartman, 1944 & 1 & 1 & & \\
\hline Notomastus sp. & & 2 & 2 & 37 \\
\hline Owenia fusiformis Claparède, 1870 & & & 6 & 54 \\
\hline Isolda pulchella Müller. 1858 & 16 & 14 & 2 & 6 \\
\hline Terebellides anguicomus Müller. 1858 & & & 1 & 1 \\
\hline Branchiomma cf.lucullana (delle Chiaje, 1828) & & & 1 & \\
\hline Branchiomma nigromaculata (Baird, 1865) & 1 & 1 & 2 & 2 \\
\hline Megalomma bioculatum (Ehlers. 1867) & & & 4 & \\
\hline TOTAL & 453 & 713 & 198 & 473 \\
\hline
\end{tabular}


11 a 10 inds. $10,23 \mathrm{~m}^{2}$

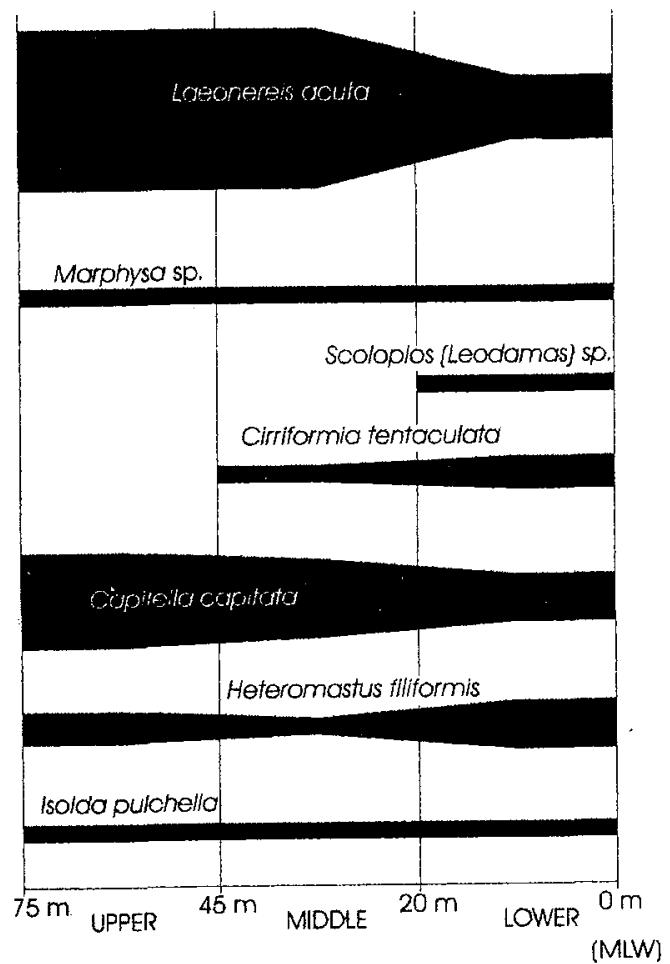

Fig. 3. Zonation of the most abundant species in the intertidal region of the Sector Barra Velha I.

11 a 10 inds. $/ 0,23 \mathrm{~m}^{2}$

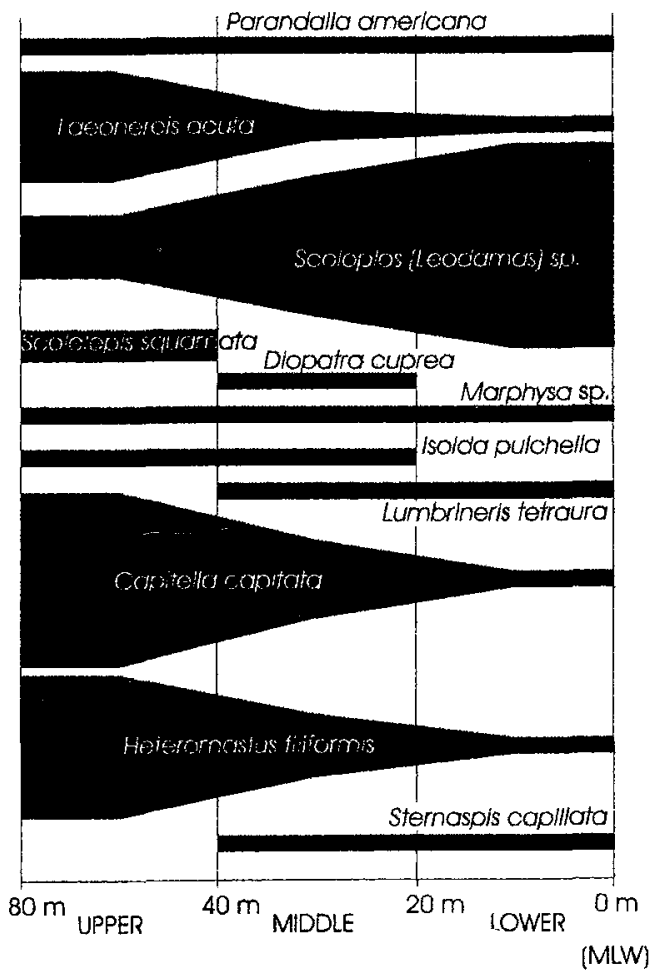

Fig. 4. Zonation of the most abundant species in the intertidal region of the Sector Barra Velha II.
1 a 10 inds $/ 0,23 \mathrm{~m}^{2}$

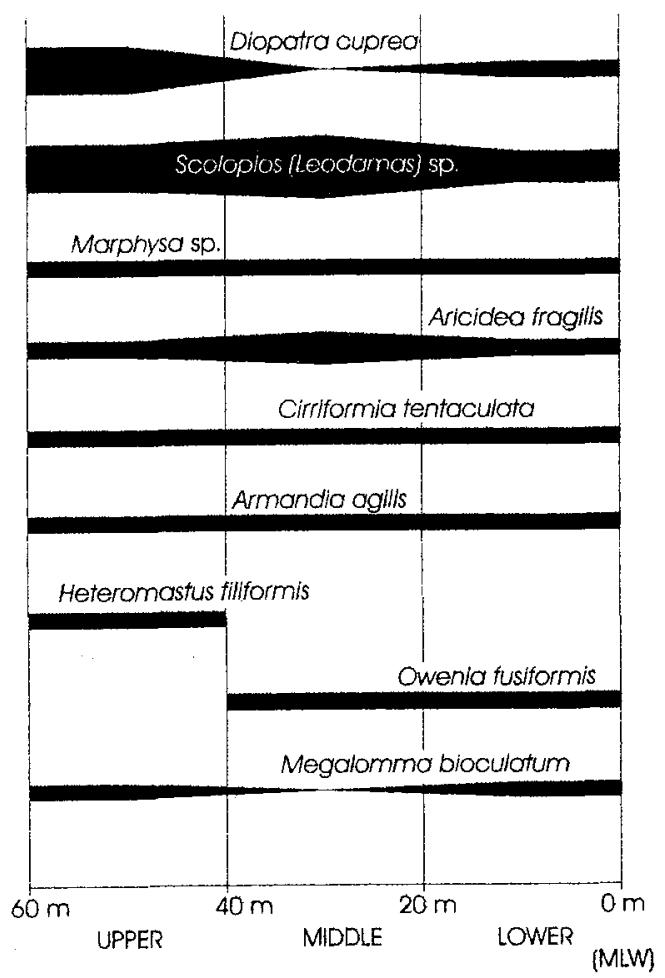

Fig. 5. Zonation of the most abundant species in the intertidal region of the Sector Perequê.

1 a 10 inds. $10,23 \mathrm{~m}^{2}$

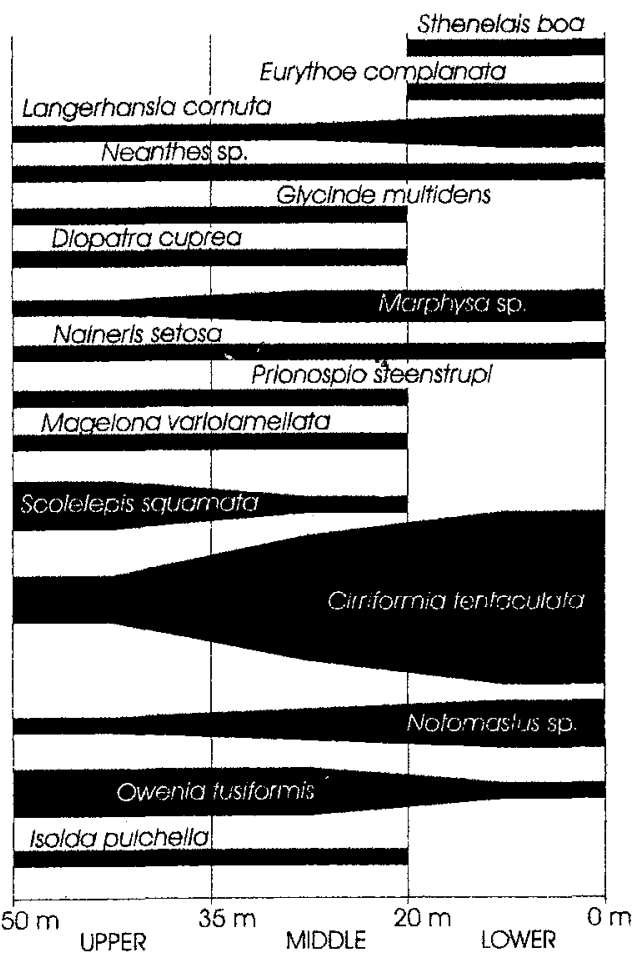

Fig. 6. Zonation of the most abundant species in the intertidal region of the Sector Engenho d'Água. 
Table 3. Abundance, diversity, evenness and richness for the different levels $\left(0.23 \mathrm{~m}^{2}\right)$ at each study sector

\begin{tabular}{|c|c|c|c|c|c|c|c|c|c|c|c|c|}
\hline & \multicolumn{3}{|c|}{ Barra Velha I } & \multicolumn{3}{|c|}{ Barra Velha II } & \multicolumn{3}{|c|}{ Perequê } & \multicolumn{3}{|c|}{ Engenho d'Água } \\
\hline & UPP & MIDD. & LOW. & UPP & MIDD. & LOW. & UPP & MIDD. & LOW. & UPP & MIDD. & LOW. \\
\hline ABUNDANCE & 174 & 156 & 123 & 334 & 214 & 165 & 83 & 69 & 46 & 103 & 179 & 191 \\
\hline DIVERSITY & 0,498 & 0.415 & 0.720 & 0,752 & 0.823 & 0.423 & 0,861 & 0.709 & 0.839 & 0.971 & 0.861 & 0.670 \\
\hline EVENNESS & 0,579 & 0.594 & 0.720 & 0,697 & 0.683 & 0.392 & 0,700 & 0.619 & 0.777 & 0,789 & 0.686 & 0.570 \\
\hline RICHNESS & 7 & 5 & 10 & 12 & 16 & 12 & 17 & 14 & 12 & 17 & 18 & 15 \\
\hline
\end{tabular}

Canonical correspondence analyses ordered the species according to their distribution in the intertidal region, ranking the environmental variables in importance (Fig. 7). Laeonereis acuta, $H$. filiformis, and C. capitata were strongly related to the sectors of Barra Velha Beach, where salinity was low and organic matter content high. In contrast, Owenia fusiformis occurred mainly in Engenho d'Água. Scoloplos (Leodamas) sp. and D. cuprea showed a strong positive relationship with finer, well-sorted sediments. Cirriformia tentaculata and Notomastus sp. tended to occur in environments composed of coarse sediment with low organic matter content.

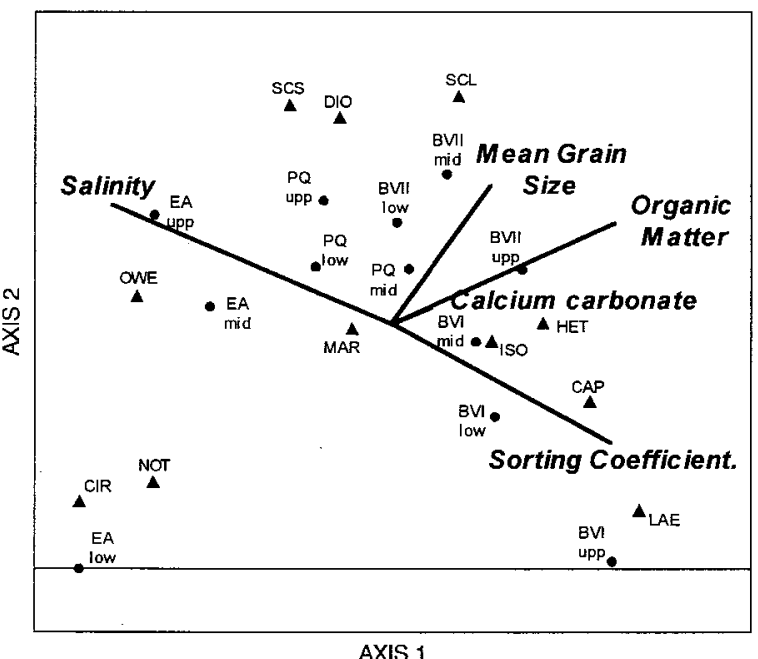

Fig. 7. Canonical Correspondence Analysis (CCA) of the most abundant species and of the levels/sectors in relation to environmental variables (total variation explained by axis $1=64.0 \%$, and by axis $2=19.8 \%$ ). CAP $=$ Capitella capitata $;$ CIR $=$ Cirriformia tentaculata; DIO = Diopatra cuprea; HET = Heteromastus filiformis; ISO = Isolda pulchella; $\mathrm{LAE}=$ Laeonereis acuta; $\mathrm{MAR}=$ Marphysa sp.; NOT $=$ Notomastus sp.; OWE $=$ Owenia fusiformis; $\mathrm{SCS}=$ Scolelepis squamata; $\mathrm{SCL}=$ Scoloplos (Leodamas) $\mathrm{sp}$. The study sectors: BVI and BVII (Barra Velha I and II); PQ (Perequê) and EA (Engenho d'Água) at the different tidal levels: lower (low), middle (mid) and upper (upp).

\section{Discussion}

Some species established an obvious zonation pattern in abundance, making it possible to infer their preferences for intertidal zone occupation. Laeonereis acuta showed a wide distribution, but reached its highest population densities in the upper levels of Barra Velha Beach (Sectors I and II), where the salinity oscillated strongly. Although recorded in all types of sediment, this species tended to occur in coarse grains. These results were similar to those obtained by Amaral (1979) and Corbisier (1991) in Ubatuba and Santos (São Paulo State), respectively, and by Elias (1992), who related its occurrence to adjacent freshwater runoff. The presence of a small rivulet may have caused the salinity fluctuations $(6 \%$ in the spring to $32 \%$ in the summer) that we observed in the upper level of this area, enabling the dominance of euryhaline species such as $L$. acuta (Amaral et al., 1995). Morgado et al. (1994) found this species in organically enriched medium and fine sediments in sandy beaches of São Sebastião Channel.

Capitella capitata was also frequent in the upper tidal levels of the beach, as observed earlier (Dauer \& Simon, 1975; Amaral, 1979; Shackley, 1981; Read, 1984; Amaral et al., 1990; Corbisier, 1991). The occurrence of this species is related to fine and medium sediments (Fauchald \& Jumars, 1979; Shackley, 1981) or with mud flats (Butman \& Grassle, 1992), which agrees with the results obtained in this study, on species dominance in fine and poorly sorted sand. Capitella capitata has also been reported from sheltered environments (Dauer \& Simon, 1975) and organically enriched ones (Cognetti, 1972; Barnett, 1984; Mora et al., 1989; Butman \& Grassle, 1992; Amaral et al., 1998). Certainly, high organic matter content and low salinity are factors influencing the distribution of this species.

Heteromastus filiformis also showed dominance in the upper tidal levels. However, Read (1984) found $H$. filiformis exclusively close to the water line, and considered it as a subtidal species that 
extends into the intertidal region. The species can tolerate wide oscillations of salinity and different sediment types (Read, 1984), occurring frequently in organically enriched locations (Dauer \& Conner, 1980; Beukema, 1991; Morgado et al., 1994; Amaral et al., 1998). This species attained a high population level in the Barra Velha Beach, a known polluted environment, where it occurred predominantly in finer sediments.

The previously mentioned species $L$. acuta, C. capitata, and $H$. filiformis maintained a stable distribution pattern in these study sites. In studies done in 1990 in the same areas, these species showed high frequencies in the upper levels of the intertidal region (Amaral et al., 1995), where there was strong evidence of organic enrichment, and were therefore considered bioindicators of pollution (Amaral et al., 1998).

Scoloplos (Leodamas) sp. was also abundant in environments composed of organically enriched, finer sediments, but with slight changes in interstitial salinity, as in the lower and middle tidal levels of Barra Velha II. These results are similar to those obtained by Lopez-Cotelo et al. (1982) for $S$. armiger, which was recorded in the middle levels of sheltered and organically enriched beaches, and by Shackley (1981), who related it to moderately selected fine sediments. Species of the genus Scoloplos are dominant in polluted estuaries and organically enriched mixohaline waters (Fauchald \& Jumars, 1979). The dominance of Scoloplos (Leodamas) sp. caused the decrease in diversity and evenness in the lower tidal level of Barra Velha II. The species was also well represented in the middle tidal level of Perequê, where the sediment is coarser and the organic matter content lower than in Barra Velha II.

Diopatra cuprea is commonly found in the lower intertidal level on the sandy beaches of southeastern Brazil. However, it tended to occur in the upper levels of Perequê. This was probably because of the presence of sandbars covered by the seagrass Halodule sp. in the lower tidal level, causing a onger period of emersion in this level compared to the middle and upper levels.

In Engenho d'Água, the species distribution was more heterogeneous, probably because of the slight variation in environmental factors along the intertidal region. Scolelepis squamata occurred predominantly in the upper tidal level, together with $O$. fusiformis, which maintained the same density in the intermediate level. More than $50 \%$ of individuals of the cirratulid $C$. tentaculata occurred in the lower tidal level, where the sediment was coarser. Gruet (1974) considered this species as typical of the subtidal level, and abundant under stones such as in Engenho d'Água. Bestwick et al. (1989) reported that it occurred mainly in the intermediate levels of the intertidal region.

In general, the areas near the waterline in sandy beaches are little influenced by changes in the environment, decreasing physiological stress on the inhabitants. Nevertheless, the number of species tended to decrease from upper to lower tidal levels in the sites studied (except in Barra Velha I), in opposition to the general tendency reported in the literature (Day \& Morgans, 1956; McLachlan, 1977; Amaral, 1979; Dexter, 1983; Haynes \& Quinn, 1995). In Barra Velha I, the lower tidal level showed high diversity, as well as in the three levels of Perequê where no single species dominated. The marked dominance of Scoloplos (Leodamas) sp. and C. tentaculata, respectively, caused a decrease in diversity in the lower tidal levels of Barra Velha II and Engenho d’Água.

The sandy beaches in the central and northern part of São Sebastião Channel have sediments composed of a mixture of different sand types, which support the existence of a large number of species. Other variables, as salinity, organic matter content, sediment moistness, slope, and environmental heterogeneity also can contribute to or regulate the species presence in a particular level. The principal factors affecting the occurrence and intertidal distribution of species were: at Barra Velha I, wide oscillations in salinity; at Barra Velha II, organic enrichment; at Perequê, the presence of sandbars covered by the seagrass Halodule sp. and the gentle slope, which allow the lower tidal level to remain more exposed than other levels during low tide; and at Engenho d'Água, the presence of rock fragments associated with the gentle slope, creating small tide pools and moist microhabitats.

\section{Acknowledgements}

To the Conselho de Amparo à Pesquisa (CAPES) and the Fundo de Apoio à Pesquisa (FAEP-UNICAMP) for their grants for this study. To the Centro de Biologia Marinha (CEBIMar-USP) for logistics support. To Mr. Élcio Soares Marinho (IB - UNICAMP), and the technicians of CEBIMar-USP, who assisted in the fieldwork. To biologist Alexander Turra for his collaboration in the statistical analysis and manuscript revision. To Dr. Janet W. Reid for revision of the English text. 


\section{References}

Amaral, A. C. Z. 1979. Ecologia e contribuição dos anelídeos poliquetos para a biomassa bêntica da zona entremarés no litoral norte do Estado de São Paulo. Bolm Inst. oceanogr., S Paulo, 28(1):1-52.

Amaral, A. C. Z.; Morgado, E. H.; Lopes, P. P.; Belucio, L. F.; Leite, F. P. P. \& Ferreira, C. P. 1990. Composition and distribution of the intertidal macrofauna of sandy beaches on São Paulo coast. In: SIMPÓSIO DE ECOSSISTEMAS DA COSTA SUL E SUDESTE BRASILEIRA: ESTRUTURA, FUNÇÃO E MANEJO. 2. Àguas de Lindóia, 1990. São Paulo, ACIESP, 71(3):258-279.

Amaral, A. C. Z.; Morgado, E. H.; Pardo, E. V. \& Reis, M. O. 1995. Estrutura da comunidade de poliquetos da zona entremarés em praias da Ilha de São Sebastião (SP). Publção esp. Inst. oceanogr., S Paulo, (11):229-237.

Amaral, A. C. Z.; Morgado, E. H.; Salvador, L. B. 1998. Poliquetas bioindicadores de poluição orgânica em praias paulistas. Rev. Brasil. Biol., 58(2):307-316.

Amoureux, L. 1966. Ëtude bionomique et écologique de quelques annélides polychètes des sables intertidaux des côtes ouest de la France. Archs. Exp. gén., 107:1-218.

Bally, R. 1983. Intertidal zonation on sandy beaches of the west coast of South Africa. Cah. Biol. mar., 24(1):85-103.

Barnett, B. E. 1984. Observations on the intertidal fauna of the South Bank of the Humber Estuary. Mar. environ. Res., 13(1):33-53.

Bestwick, B. W.; Robbins, I. J. \& Warren, L. M. 1989. Metabolic adaptations of the intertidal polychaete Cirriformia tentaculata to life in a oxygen-sink environment. J. expl. mar. Biol. Ecol., 125(3):193-202.

Beukema, J. J. 1991. Changes in composition of bottom fauna of a tidal-flat area during a period of eutrophication. Mar. Biol., $111(2): 293-301$.

Brown, A. C. \& McLachlan, A. 1990. Ecology of sandy beaches. Amsterdan, Elsevier. 327p.
Butman, C. A. \& Grassle, J. P. 1992. Active habitat selection by Capitella sp. I larvae. I. Two-choice experiments in still water and flume flows. J. mar. Res., 50(4):669-715.

Cognetti, G. 1972. Distribution of polychaeta in polluted waters. Rev. Int. Oceanogr. Méd., 25: 23-34.

Corbisier, T. N. 1991. Benthic macrofauna of sandy intertidal zone at Santos estuarine system, São Paulo, Brazil. Bolm Inst. oceanogr., S Paulo, 39(1):1-13.

Dahl, E. 1953. Some aspects of the ecology and zonation of the fauna on sandy beaches. Oikos, $4(1): 1-27$.

Dauer, D. M. \& Simon, J. L. 1975. Lateral or along shore ditribution of polychaetous annelids of an intertidal, sandy habitat. Mar Biol., 31(4):363370.

Dauer, D. M. \& Conner, W. G. 1980. Effects of moderate sewage input on benthic polychaete populations. Estuar. coast. mar. Sci., 10(3):335346.

Day, J. H. \& Morgans, J. F. C. 1956. The ecology of South African estuaries. 7. The biology of Durban Bay. Ann. Natal Mus., 13:259-312.

Dexter, D. M. 1983. Community structure of intertidal sandy beaches in New South Wales, Australia. In: McLachlan, A. \& Erasmus, T. eds Sandy beaches as ecosystems. Port Elizabeth, The Hague Dr. W. Junk Publ. p. 461-472.

Dexter, D. M. 1988. The sandy beach fauna of Portugal. Arqs. Mus. Bocage, Nova Ser., 1(8): 101-110.

Elias, R. 1992. Quantitative benthic community structure in Blanca Bay and its relatinship with organic enrichment. Mar. Ecol., 13(3):189-201.

Fauchald, K. \& Jumars, P. A. 1979. The diet of worms: a study of polychaete feeding guilds. Oceanogr. mar. Biol. a. Rev., 17:193-284.

Furtado, V. V. \& Mahiques, M. M. 1990. Distribuição dos sedimentos em regiões costeiras e plataforma continental norte do Estado de São Paulo. In: SIMPÓSIO DE ECOSSISTEMAS DA COSTA SUL E SUDESTE BRASILEIRA - ESTRUTURA, FUNÇÃO E MANEJO. 2. Águas de Lindóia, 1990. Anais. São Paulo, ACIESP, 71(1):20-29. 
Gruet, Y. 1974. Macrofaune des substrats meubles intertidaux entre le Pont $D^{\prime}$ Yeu et Sion-SurL'Ocean (Vendee). Bull. Soc. Sci. nat. Ouest Fr., 72:12-28.

Haynes, D. \& Quinn, G. P. 1995. Temporal and spatial variability in community structure of a sandy intertidal beach, Cape Paterson, Victoria, Australia. Mar. Fheshwater Res., 46(6):931942.

Hill, M. O. 1979. Twinspan- A Fortran program for arranging multivariate data in a ordered twoway table by classification of the individual and attributes. Ithaca, New York, Cornell University. $318 \mathrm{p}$.

Krebs, C. J. 1989. Ecological metodology. New York, Harper Collins. 654p.

Lopez-Cotelo, I.; Vieitez, J. M. \& Diaz-Pineda, F. 1982. Tipos de comunidades bentonicas de $\mathrm{La}$ Playa del Puntal (Bahia de Santander). Cah. Biol. mar., 23(1):53-59.

McLachlan, A. 1977. Composition, distribution, abundance and biomass of the macrofauna and meiofauna of four sandy beaches. Zool. Afr., $12(2): 279-306$.

McLachlan, A. 1983. Sandy beach ecology- a review.: In: McLachlan, A. \& Erasmus, T. eds. Sandy beaches as ecosystems. Port Elizabeth, The Hague Dr. W. Junk Publ. p.321-380.

McLachlan, A.; Wooldridge, T. \& Dye, A. H. 1981. The ecology of sandy beaches in Southern Africa. S. Afr. J. Zool., 16(4):219-231.

McLachlan, A. \& Jaramillo, E. 1995. Zonation on sandy beaches. Oceanogr. mar. Biol. a. Rev., 33: 305-335.

Mora, J.; Planas, M. \& Silva, R. 1989. Impacto de la contaminacion orgánica en la ensenada de Lourizan (Proyecto Escorp). I. El medio físico y la macrofauna bentónica. Cah. Biol. mar., 30(2):181-199.
Morgado, E. H.; Amaral, A. C. Z.; Nonato, E. F. \& Salvador, L. B. 1994. Intertidal sandy beaches polychaetes of São Sebastião Island, southern Brazil. Mém. Mus. natn. Hist. nat., 162:485492.

Read, G. B. 1984. Persistence of infaunal polychaete zonation patterns on a sheltered, intertidal sand flat. N. Z. J. Mar. Fre. Res., 18(4):399-416.

Salvat, B. 1964. Les conditions hydrodynamiques interstitielles des sédiments meublés intertidaux et la repartition verticale de la faune endogènee. C. r. Acad. Sci., Paris, 259:1576-1579.

Shackley, S. E. 1981. The intertidal soft sediments and their macrofauna in the greater Swansea Bay Area (worm's head to Nash Point), South Wales. Estuar. coast. Shelf Sci., 12(5):535-548.

Suguio, K. 1973. Introdução à sedimentologia. São Paulo, Edgard Blucher/EDUSP. 317p.

Veloso, V. G.; Cardoso, R. S. \& Fonseca, D. B. 1997. Adaptações e biologia da macrofauna de praias arenosas expostas com ênfase nas espécies da região entre-marés do litoral Fluminense. Oecologia Brasiliensis: Ecologia de Praia Arenosas do Litoral Brasileiro, 3:135-154.

Vohra, F. C. 1971. Zonation on a tropical sandy shore. J. Anim. Ecol., 40(3):679-708.

Wendt, G. E. \& McLachlan, A. 1985. Zonation and biomass of the intertidal macrofauna along a south African sandy beach. Cah. Biol. mar., 26(1):1-14

(Manuscript received 18 April 2000; revised 03 July 2000; accepted 16 October 2000) 